\title{
Comedic Resilience: Arab Women's Diaries of National Struggles and Dissident Humour
}

\author{
Hiyem Cheurfa
}

\begin{abstract}
:
This article explores the potential strategic functions of humour in diaries that record national struggles by contemporary Arab women, namely Palestinian author Suad Amiry's Sharon and my Mother-in-Law: Ramallah Diaries (2006) and Egyptian writer Mona Prince's Revolution is my Name: an Egyptian Woman's Diary from Eighteen Days in Tahrir (2014). Drawing on existing research into postcolonial and feminist comedy, the paper argues that the use of humour to articulate revolutionary moments constitutes what I describe as 'comedic resilience' through which comedy is intentionally, reflectively, and strategically deployed by the authors under discussion as a dissident strategy to intersectional dominant structures of power to which Arab women are subjected. This subjugating, concentric power structure comprises colonial/state hegemony, nationalist dogmatism, local and external patriarchies, and cultural/ representational silencing. Equally, I consider the ways in which the intersection of war diary-writing and comedy problematises the representational literary traditions of national struggles. Using humour in contexts where they are expected to grieve, the authors under scrutiny rework the conventional understanding of war life-writing and with it the role and position of Arab women in militarized contexts of conflicts.
\end{abstract}

Key words: Arab women; Life-writing; Arab humour; Resistance literature; Palestinian lifewriting; Egyptian revolution. 


\section{Introduction:}

In what follows, the article explores the potential strategic functions of humour in diaries of national struggles by two politically-committed Arab women life-writers, namely Palestinian author and architect Suad Amiry, and Egyptian professor and translator Mona Prince. I consider the use of humour to deal with and write about revolutionary moments as an intentional strategy of dissidence used against a concentric structure of power to which Arab women in politicallyfraught contexts are subjected; comprising state/colonial, patriarchal, and representational hegemonic discourses. Both diaries under scrutiny represent insider's daily accounts of national struggles that are testimonial in essence as they stem from the writing subject's own experience as participants and witnesses of the events narrated. Although the texts are differently located, in Palestine and Egypt respectively, both are characterized by the humorous articulation of the subjects' experiences of curfews and life under militarization. Both authors, the paper argues, are reworking the conventional understanding of non-fictional accounts of war and national struggles through the comedic articulation of revolutionary moments and historically-significant national contexts. War is not funny, yet engaging with it and representing it in a humorous manner particularly from the side of the victim evokes the intersection between the tragic and the comic while highlighting the potential significance of humour in destabilizing existing power dynamics. Equally, I explore the ways in which each author deploys humour to address issues of gender and make visible women's status and activism in contexts of national conflicts.

The extensive theoretical conceptualization of humour, which can be traced as far back as Greek Antiquity, has failed to reach a consensus on the definitions and functions of this universal phenomenon. Throughout history, the function of humour has been variedly perceived as: a cognitive reaction to (perceived) incongruity (Hutcheson 1750, Beattie 1778), an emotional 
response to repressed energy and desires (Freud 1960), a medium for social integration (Frye 1965), a form of privileging and exclusion through derision (Hobbes 1991), a desire for (cultural) appropriation (Bhabha 2004), and a disavowal of (socio-political) otherness and stereotypical categorization (Bhabha 2004; Barreca 1994). While mainstream humour theorists have disagreed upon a unified category of humour and its functionality (Carroll 2014, 6,7), postcolonial and feminist theorists have generally contended that the use of humour from a socio-politically marginalized position, by virtue of political and material imbalance, cultural difference, ethnicity, and/or gender, is linked to power (Barreca 1994, Gilbert 2004, Reichl and Stein 2005, Zwagerman 2010). Structures of power motivate both a postcolonial perspective and women's humour studies because 'laughter seems to thrive in a situation of power imbalance and even oppression' (Reichl and Stein 2005, 12). While the political function of humour has been perceived as ranging from maintaining power discourses through comedic legitimization, to challenging them through ridicule, postcolonial and feminist humour are often reactive. Postcolonial comedy primarily 'reflect[s] a struggle for agency, an imbalance of power, and a need, a desire, for release' (ibid, 9). Analogously, 'feminist humour is always, at some level, subversive [...being] both angry and affirming' (Gilbert 2004, 31); it is generally 'a force for [...revisionist] action' (Zwagerman 2010, 3).

The notion of otherness that is constructed through laughter is particularly relevant to postcolonial and feminist contexts in which the centre-margin dynamic is intrinsic. According to superiority theory of humour, laughter entails exclusion because it emerges as a reaction to the perception of differences in others as infirmities that the laughing subject supposedly transcends (Hobbes 1991, 43). This process of hierarchical division poses ethical questions, especially when the target of humour is an already marginalized group. However, laughing from a position of 
marginality, which is structured through material power, gender, and/or race, is arguably a form of resistance to otherness and socio-political categorization; it empowers the laughing subject who attempts deliberately at destabilizing the subjugating powers by whom he/she has historically been ridiculed. This from of marginal humour contemplates power on a variety of levels: it targets dominant discourses in an attempt to distort its authority through derision; using self-deprecation, it turns marginality into a subject of ridicule in order to address power imbalance by ridiculing none other than itself; it consciously exposes the incongruity of existing stereotypical hierarchies through laughter; and it acts, in Sigmund Freud's conceptualization (1960), as a psychological safety-value, a form of aggression-release that aims at creating a collective complicity among a given marginalised group against a common hegemony. ${ }^{\text {ii }}$

Both postcolonial criticism and feminist studies are particularly interested in the hierarchical relations that might be distorted by and dismantled through humour. While the interplay between superiority and inferiority, exclusion and inclusion, tension and relief, all working on different socio-political and psychological levels, directly falls under the concerns of postcolonial theory (Reichl and Stein 2005, 7, 9; Illot 2015, 135-138), it serves to extend a gendered investigation of postcolonial humour, which continues to be under-researched. While both spheres have developed a relative academic interest in humour in recent years, ${ }^{\text {ii }}$ Arab humour continues to be fairly under-researched and untheorized, especially in existing materials in English. Known as 'hazl' (farce), 'tahakkum' (taunt) and 'sukhri'iya' (poking fun, including forms of sarcasm and irony, and hence literary humour is termed al-Adab al-Sākher), ${ }^{\mathrm{iv}}$ contemporary comedy from the Arab world appears to be inherently political and, as Raoudha Kammoun asserts, transgressive: in the Arab world, 'humour and social upheavals go hand in hand' $(2010,252)$. The recent upheavals in the region, or what have been dubbed 'The Arab Spring' - starting in 2011, 
have signalled the public's growing desire for democracy and freedom of expression and highlighted the revolutionary potential of humour as a strategy towards possible subversion of the dominant socio-political status quo (Cooke 2017, 39). These events have enabled the public emergence and disclosure of different forms of dissident humour, such as political jokes, cartoons, graffiti, and stand-up shows, and therefore encouraged academic discussions on the socio-political significance of contemporary Arab humour in a variety of cultural forms (see, for instance, Abaza and Mehrez 2016; Cooke 2017; Awad and Wagoner 2017; Helmy and Frerichs 2017). Hence, this article aims to join the current growing research on Arab humour by extending the discussions to a gendered investigation of comedy in the diary genre by contemporary Arab women while drawing on existing postcolonial and feminist theories on the subject.

\section{Mocked Occupation and the Daily Palestinian Absurd:}

In the preface to her diary, Sharon and My Mother-in-Law: Ramallah Diaries (2006), Palestinian author Suad Amiry acknowledges her friend Bilal Hammad for teaching her 'how to step out of the frame and observe the senselessness of the moment' $(2006$, xi). This act of perceptive transgression becomes the principle around which Amiry's daily account of life under occupation is constructed. Amiry composes an intriguing account that moves away from other non-fictional Palestinian war narratives by virtue of its overwhelmingly humorous tone. Resorting to irony, wit, and sarcasm, the diarist presents a fresh perspective of daily life in the contemporary Palestinian scene by offering a new representational paradigm that escapes the traditionally tragic and/or heroic frames of writing personal war accounts. The intersection of humour and war diarywriting in the text under discussion offers an alternative representational framework of the Palestinian reality, one which is positioned within the unheroic, the absurd, and the routinely, instead of the (sometimes crudely) political and overwhelmingly lyrical frames within which the 
Palestinian/Israeli conflict is generally conceived and depicted; a representational approach which constitutes an 'innovative construction of a "Palestinian Absurd"' (Moore-Gilbert 2009, 126).

The comedic quality of Amiry's diary is primarily announced through the intriguing title of the account in which Ariel Sharon, ${ }^{v}$ the Israeli ex-prime minister, is equated with the narrator's 91-year-old mother-in-law, Um Salim. While this equation between two figures who exist on two ends of a power spectrum appears incongruous, and thus laughable, it acts primarily to reflect the variant forms of oppression to which the narrator is subjected: the political and the domestic. Most importantly, I believe that this comedic equation of the political hegemony with the daily domestic skirmishes is a conscious representational strategy that is aimed at de-emphasising the effectiveness of colonial rule on everyday life. It thus engages in a symbolic process of depriving it of its supposed power by reducing it to the daily, routinely, and domestic. Such a perceptive process, which is carried throughout the narrative, enables Amiry to 'step out of the [established] frames' of conceiving and representing the Israeli occupation of Palestine. To break out of the representational frame, for Judith Butler, 'is to show that the frame never quite contained the scene it was meant to limn'; it is to suggest 'a loosening of the mechanism of control' $(2009,8-9,11)$. It is through this breakage that Amiry comes to the knowledge that living by and writing within the conventional scope of perception that attributes certain characteristics to occupation is to conform to the authority that generates and defines it; hence, to call such a frame into question occurs only once she steps out of it. This transgressive movement allows her to question the very foundations of occupation by observing the 'absurdity of my life and the lives of others' in occupied Ramallah (2006, xi).

Amiry's diary, which was not intended for publication, being initially written in epistolary forms (letters and emails) addressed to a selected group of relatives and friends, started as a form 
of therapy. In her preface, Amiry explains that writing her daily account 'was an attempt to release the tension caused and compounded by Ariel Sharon and my mother-in-law' (2006, x). While psychological relief, or 'healing', is a central characteristic of testimonial writings (Henke 1998, xix $),{ }^{\mathrm{vi}}$ it is particularly the use of humour in this text that accelerates such a releasing process. Throughout the narrative, Amiry self-consciously resorts to comedy to deal with, to escape, and to report the arbitrary scenarios which she, as a daughter-in-law of a demanding elderly woman and as a Palestinian living under occupation, consistently encounters.

On one level, Amiry resorts to humour as a sanity-preserving strategy to escape the domestic pressure exercised on her by her widowed mother-in-law. After evacuating Um Salim from the militarized area where she lives, Amiry finds herself obliged to spend the monotonous days of curfews with a tyrannical president in the house. The latter, a nagging woman with a fluctuating temper and scrupulous habits and schedule, deprives Amiry of her privacy, criticizes her 'odd hours', and attempts to impose her own routine on her daughter-in-law. As a reaction, Amiry self-consciously turns her mother-in-law into a subject of her humour; she laughs at Um Salim who is more concerned about her marmalade being spoiled than the Israeli tanks positioned outside the house. She laughs at her immaculate outfits and attention to domestic details in an antagonistic colonial context $(2006,137,141)$. Amiry's humour, being primarily addressed to her own enjoyment, comes as an act of social self-protection that allows her to elicit self-amusement from domestic tension, and hence, symbolically survive it. Her comedy thus constitutes, in the Freudian understanding, a release of repressed energy that is accumulated through social repression; it allows her to liberate domestic pressure which would only complicate her own experience of occupation. Choosing to share these scenes comedically, Amiry, again, evokes 
Freud's comedy triangle, ${ }^{\text {vii }}$ by soliciting her correspondents' laughter, sympathy, and complicity against her mother-in-law, and hence extends and enhances the relief function of her humour.

While domestic humour in the case of Amiry acts primarily to release the tension built-up by her mother-in-law, her comedic attitude towards occupation bypasses the psychological function to become potentially subversive. Indeed, Amiry ridicules occupation in order to dislocate her fear and anxiety and to ease her pain and sense of oppression. Humour is used, at times, as a form of denial which seems, as she writes, 'an effective way of dealing with the unbearable encounters of life under occupation' $(2006,189)$. However, while the psychological function of comedy remains relevant, Amiry's humour against occupation can be understood, in Regina Barreca's theorization of women's humour, as 'an ideological construct' $(1988,7)$ that is manifested under the guise of the personal, the funny, and the daily. Women's humour against power goes beyond the conventional theorization of comedy 'as catharsis of desire and frustration; [and] comedy as social safety value' to constitute a means of questioning, interrogating, and challenging the legitimacy of the ridiculed authority (Barreca 1994, 18). Israeli rule in Amiry's text is a consistently mocked occupation. Such mockery does not solely aim to dismiss anxiety but to de-legitimize the very foundations of occupation through laughter. While the Israeli/Palestinian conflict is indeed 'a clash between [...] "two narratives"' (Bernard 2013, 6), Amiry's (textual) humour allows her not only to advocate her stance vis-à-vis the occupier and respond to its dominant narrative but also to ridicule it, and hence to attempt to destabilise existing dynamics of power discourses. Presenting the political through the personal and the serious through the humorous, Amiry raises questions concerning the mechanisms of occupation by exposing the farcical nature of its own subjugating dynamics because, as she justifies it, 'we're never sure how serious or unserious this occupation is' $(2006,59)$. 
Throughout the narrative, the absurdity of colonial rule is consciously exposed through laughter. The oppressive regulations to which Amiry, as a Palestinian woman living in occupied Ramallah, is subjected are rendered in a comedic disjuncture that shifts from the serious to the ludicrous. For instance, while most West Bankers need a permit to travel to Jerusalem, which they can rarely get, Amiry's dog Nura receives a Jerusalem passport after being examined by an Israeli veterinarian. Astonished by the irony of the situation having lived sans-papiers in her own country for 7 years, Amiry decides to drive to Jerusalem and make use of the privileged dog's documentation. 'I am the dog's driver' she tells the amused soldier at a checkpoint while handing him the dog's passport, 'she is from Jerusalem, and she cannot possibly drive the car or go to Jerusalem all by herself [...] somebody has got to be her driver' $(2006,108)$. Such a juxtaposition between the serious and the comedic inevitably foregrounds the incongruous nature of the colonial rule which, as absurd as it may sound, guarantees the mobility of animals while arbitrarily controls the spatial, and in effect the temporal, dimensions of the life of millions of Palestinians. ${ }^{\text {viii }}$ Surprisingly, Amiry convinces the entertained soldier and is permitted access to Jerusalem because 'all it takes is a bit of humour' (2006, 108). Humour thus becomes, as Sean Zwagerman notes, 'a force for $[\ldots]$ action'; it proves to be practically reactive as it demonstrates that if humour is 'a way of speaking, it is also a way of acting and a way of moving between -and conceptualizing the movement between -the mind, the word, and the world' $(2010,3,191)$.

However, Amiry's humour is not exclusively directed towards the tyrannical figures foregrounded in the title of her diaries. Amiry's laugher indiscriminately targets her own compatriots through unfolding a social criticism which demonstrates that 'occupation has ruined the spirit of both Israelis and Palestinians' $(2006,11)$. While Palestinian cultural behaviour and cases of collaboration with the occupiers on the one hand and Israeli political attitudes on the other 
provide Amiry with rich material for jokes, it is the patriarchal inclination that brings Palestinian and Israeli men under a shared banner of a ridiculed power. Amiry asserts that patriarchy 'makes the occupation doubly painful' $(2006,67)$ as Palestinian women find themselves eventually unable 'to define who the enemy is' $(2006,92)$. Gender-based treatment, which the author sarcastically describes as 'the only Arab tradition the Israeli seem to reinforce' $(2006,190)$, extends the targets of her humour and with it her avenues of comedic resistance against both external and local (masculine) subjugating powers.

Amiry's consciousness of, and explicit reference to, her position as subjected to a genderbased intersectional power structure allow her not only to reflect but most importantly to engage in different axes of resistance using self-deprecatory humour. The latter generally stems from her peripheral position constructed, as she experiences it, on the basis of her colonial status, gender, and age. Barreca argues that women's humour 'derive[s] power from their exclusion' $(1988,16)$ and Joanna Gilbert maintains that gendered exclusion 'may ultimately serve as a powerful means of resistance to social, political, and economic inequities' (2004, 5). Similarly, through selfdeprecation, Amiry capitalizes on and takes advantage of her socio-politically-constructed gendered position because, as Gilbert argues, 'individuals who are sociologically marginalized [...] by some immutable physical reality such as sex, race/ ethnicity, age, size or disfiguration/ disability $[\ldots]$ cannot help but perform their marginality' $(2004,6)$. In Amiry's text, the comedic performativity of gender, in the Butlerian sense of the reproduction of socially-constructed conventions of gender (1990), enables the laughing subject to turn the stereotypical frame within which she is identified into a privileged position of resistance. While Butler problematises the agency of the actors who subscribe to gendered social norms, ${ }^{\mathrm{ix}}$ Amiry, I argue, provides an agential model of gender performativity. In the case of Amiry, the reproduction of gender constructs does 
not merely constitute enacting the socially-expected role in order to subscribe to dominant norms; it rather capitalizes on self-consciousness of the context, setting, and effect(s) within which this role is intentionally mimicked and reworked.

Using self-deprecation, Amiry does not hesitate to describe herself as a paranoid, 'early menopausal woman' $(2006,67)$ and expose her tears, feminine vulnerability, and anxieties within a comedic frame. Laughing at oneself, I suppose, can act as a self-defence mechanism; it prevents others from making you the target of their jokes as it reflects recognition of and even reconciliation with one's own supposed defects and state of being. However, when arising from outside (sociopolitical) positions of power, self-mockery becomes conflated with subversion as it constitutes a means through which 'social outcasts call attention to their subordinate status' (Gilbert 2004, xi, 21). Although Amiry's self-deprecation may appear to stress her inferiority and confirm her gendered stereotypes by reproducing them, it nonetheless reflects her recognition of her position as a Palestinian woman at the periphery of the social and political centres: 'being a woman helped me not to be taken seriously' (Amiry 2006, 29). Ultimately, she makes of this position a site for interrogating the power dynamics that generate and subscribe to such ideals. Through a powerful intersection between object and subject of humour, Amiry's self-deprecation highlights the fundamental ludicrousness of the dynamics of socio-political categorization and exclusion under occupation by enabling the subject laughing (at herself) to draw attention to the gender-based injustice of her own status.

Amiry chooses to engage with her gendered stereotypical image and turns it into a site of comedic resistance that, I propose, reworks the conventional image of the war hero. She takes advantage of the stigma of the weeping, emotional menopausal woman. After her 'seven-year epic' without a hawiyyeh (ID/residency card), for example, she decides that it is time to take action. She 
goes unannounced to the office of Captain Yossi from the 'Civil Administration' where she frantically delivers an emotionally-charged speech about what it means to be a Palestinian woman living under occupation. While Amiry melodramatically surrenders to tears, the astonished officer surrenders to her claim:

I could see that he was capable of handling Palestinian demonstrators, rebels, stabbers, terrorists. He could handle bombs, dynamite, tanks, fighter planes and submarines. He was able to handle them all.

BUT NOT A CRYING WOMAN.

NOT A WOMAN FREAKING OUT (2006, 43 capitals in original)

Amiry's strategic engagement with gender stereotypes in the previous incident is not only compared with the non-violent, physical, and armed forms of resistance of her male compatriots. It proves more effective and eventually triumphant, allowing her to obtain her long-awaited documentation. It equally constitutes an implied critique of existing and potential restrictions on the spheres of Palestinian women's role and agency in the national struggle which continue to be perceived under a predominantly masculine nationalist banner. ${ }^{\mathrm{x}}$ It demonstrates that women, as subordinated actors in the resistance movement, may autonomously act to preserve and restore their dignity and may eventually prove superior to both dogmatic male nationalists and occupation. In this sense, Amiry's performativity of gender becomes a strategic form of visibility that aims at redefining the intersectional spheres of women's resistance and participation in nationalist movements; it reflects what Anna Ball describes as:

[the] interplay between their colonial oppression as Palestinian, their patriarchal oppression as women and the possibilities of agency afforded by their involvement within the nationalist cause, and indeed by their positions within 'private' realms such as the home $(2012,47)$

Although the incident cited above (among others in the narrative) entails partial victory, it does not comply to the conventional understanding of the notion of heroism that is traditionally 
defined within the tropes of masculinity, extrinsic superiority, exceptionality, physicality, and bravery. It rather reworks the traditional hero by highlighting the notion of sumud. ${ }^{x i}$ Like the notion of sumud, Amiry 's laughter reflects her ability to 'maintain dignity, honour, and a physical presence in the land despite adversity and hardship' (Ryan 2015: 300). Her comedic dissidence is not necessarily passive or ineffective; similar to the defining aspects of sumud, it is a form of resilience that arises from her 'ability to remain [joyfully and triumphantly] in place in the face of indignities, injustices and humiliation at the hands of the colonial power' (El-Said et al. 2015, 13). For instance, resorting to 'alternative strategies' of resistance (Amiry 2006, 28), Amiry, in a hilariously reported episode, chooses to get her own back on a soldier in a checkpoint who calls her hajjeh $(2006,67){ }^{x i i}$ As a reaction to the sexist remark and the condescending manner in which it is made, Amiry intimidates the soldier by staring ceaselessly at him: 'I kept looking at him in the eye with an expressionless face [...] A stare, and you lose your mind' $(2006,71)$. The soldier, in turn, anxiously makes a complaint against her husband Salim for not having 'the power to force your wife to behave' (ibid). Amiry's gaze simultaneously challenges the power of occupation as well as its anchored traditions of patriarchy. Describing her behaviour as 'my passive resistance to occupation' $(2006,71)$, she draws attention to the effectiveness of passive (comedic) resilience as, sometimes, the only avenue of resistance to which Palestinian women have access.

Resorting to humour as a resistance strategy, Amiry dismantles the idealized/tragic perception of the Palestinian resister/fighter as being synonymous with 'something mythological like a unicorn' (qtd. in Moore-Gilbert 2009, 115). ${ }^{\text {xii }}$ Throughout the narrative, she evokes different incidents in which her resilience is ludicrously unheroic; for instance, she finds herself signing the anti-PLO (the Palestinian Liberation Organization) statement and attending an Israeli official party fearful of deportation and hopeful to obtain her residency card. She also openly confesses that she 
gives up on her attempt to rescue her mother-in-law from her militarized neighbourhood because she fears for her own safety $(2006,28,35,133)$. Amiry demonstrates that being a Palestinian does not make one immune to cowardliness and selfishness. Using humour as a representational model and a dominant textual tonality, her account challenges the readers' expectations who generally have 'the tendency to receive Palestinian and Israeli texts as already read' (Bernard 2013, 33) being predominantly characterized by violence, trauma, loss, and grief. In this sense, the author engages in a representational project that attempts to demythologize the image of the Palestinian Muqawama by portraying it in its dailiness, ${ }^{\text {xiv }}$ vulnerability, fear, and joy while inviting her readers to laugh with her at a paradoxical colonial predicament.

\section{An Egyptian Woman's Diary of a 'Laughing Revolution':}

Mona Prince's Revolution is my Name: an Egyptian Woman's Diary from Eighteen Days in Tahrir (2014) is a predominantly hilarious account although, similar to Amiry's narrative, it is set in a period of national conflict, particularly during the Egyptian revolution of 2011. Reporting her experience during the 18 days of mass protests which brought down a thirty-year hegemonic rule of Hosni Mubarak, Prince's diary captures and engages with the spirit of the Egyptian uprising. Due to the celebratory nature of the non-violent forms in which 'the people demand[ed] the removal of the regime', ranging from sarcastic banners, satirical chants, poetry, public performances, nationalist songs, dancing, political caricatures and graffiti, social media posts, to political jokes, the Egyptian revolution was 'transformed into [...] a carnival' (Prince 2014, 174). Humour in its different manifestations is what particularly characterised the Egyptian uprising. Although the regime's violent response to the people's peaceful call for 'bread, freedom, and social justice' turned the uprising into 'a war in the midan'xv (Prince 2014, 123), it did not hinder the use 
of humour in a range of cultural media as a form of protest, resistance, and disobedience insofar as the uprising was termed 'The Laughing Revolution' (Salem and Taira 2012).

Prince's diary, published originally in Arabic (a mélange of fusha and 'ammiiya) ${ }^{\mathrm{xvi}}$ as Ismi Thawra (2012), mediates and provides a vivid example of Egyptian revolutionary humour with which the author actively engages. The account reflects in its tonality the comedic dissidence of the revolutionists, and its immediacy captures them as 'rocking between laughter and anxiety'; while their (un)certainty about the efficiency of the revolution fluctuates and their peaceful resilience to the regime's violence persists, they continue to exchange 'the latest [political] jokes' (Prince 2014, 51). Certainly, humour is not a new form of expression in Egypt. Across the Arab world, the Egyptian is known to be 'damū khafif' (literally 'having a light blood') and 'ibn nukta' (literally 'son of the joke'), which denote his/her great sense of humour; this could be attributed to variant factors, among them: the prevalence and in effect dominance of Egyptian comedy on cinema and television industries across the Arab world (Kammoun 2010, 257); the long embedded tradition of socio-political humour in Egypt since the time of pharaohs (Houlihan 2001); and the flexibility of Egyptian colloquial Arabic ('ammiiya) which gives way to the creation of variant forms of irony, parody, wit, and sarcasm that rely on a myriad of intertextual and paratextual constructs to creatively capture the socio-political reality of the country (Salem and Taira 2012). However, it is the use of humour during revolutionary moments that calls into attention the way comedy can potentially rework the relationship of the people ( $a l$-sha $b$ ) with repressive dominant discourses and ultimately revises the conventional means of popular resistance. Equally, it affects the way firsthand accounts from such fraught contexts are approached by both the writer and the reader. 
Prince chooses the diary genre to engage with and highlight the ways in which humour was instrumental in maintaining the collective spirit of the uprising, in addressing authority, and in structuring the revolutionists' dissident agenda. While setting the ground for the revolution, political humour was used to enforce people's sense of entitlement to the uprising. In an opening section entitled 'A Necessary Introduction', Prince provides the backdrop of the uprising by describing the way 'we were flooded with jokes' $(2014,2)$. Prior to the revolution, humour was used as a tool for allaying fear and anxiety. For instance, jokes on self-immolation protests in Egypt were prevalent; ${ }^{\text {xvii }}$ Egyptians joked: 'stop setting yourselves on fire, guys; there will be no one left when the revolution begins' (Prince 2014, 2). Also, pre-revolution humour was used to stress the urgency for a political change and to encourage the Egyptian people to participate in the uprising and put an end to the prevailing injustice. Jokes highlighting the corruption of the regime, its manipulative dynamics, and the way the normalization of subordination is embedded in its rule circulated widely (see, Prince 2014, 2, 3, 10).

Certainly, humour was not the direct factor that toppled Mubarak, but it played a crucial role in directing the demonstrations towards such a 'triumphant' end. During the revolution, humour, Prince tells us, was used as a form of reassurance and 'comic relief'. The protestors were eager to keep each other updated joke-wise as a way to dislocate their anxious anticipations and fear: 'despite the injuries and the visible pain on people's faces, they were [...] telling jokes' (Prince 2014: 135). The life-threatening violence of the regime is met with ambivalent laughter. For instance, displaying the ammunition with which they are attacked, the protestors comment: 'the sons of bitches are attacking us with expired weapons! They don't think we're worth new canisters. Shame on the Ministry of Interior! They are doing it on the cheap!' (61). This laughter is ambivalent because it arises from the fear and oppression on which the regime capitalises but at 
the same time challenges it by 'turning injustice and victimhood into laughable absurdity' (Cooke $2017,51)$. Surrounded by death and violence, humour becomes a sign of agency, of life and (re)birth as 'the ability to laugh at the tyrant and his henchmen helps to repair the brokenness of fearful people, once bowed over in subjection' (ibid). It also highlights the role which laughter plays in enforcing and mobilizing public dissidence movements and in bringing people together.

Prince's account reflects the way humour enabled a sense of collectivity to emerge among the protestors. Like in Amiry's narrative in which a group of Ramallah residents poke fun at Israelis' Arabic accent as a way to alienate the occupier and maintain a sense of national unity (2006: 84), revolutionary laughter in Prince's brings the revolutionists together by virtue of their shared experiences of dictatorship and common subject of ridicule. Prince describes the revolutionists as 'strangers who were no longer strangers' (2014, 104); the Egyptians of the mīdān became, as they joyfully chanted, 'one-hand'. She describes their joyful solidarity as a rejuvenation of a newfound collective national belonging: 'we had all become Egyptians again, real Egyptians' $(2014,91)$. Humour ultimately creates a national narrative of solidarity, or what Henri Bergson in his Laughter (Le Rire 1900) describes as a 'freemasonry, or even complicity' (2005, 3). This sense of collective complicity against a common enemy encourage the protestors to bravely, publicly, boldly, and sometimes aggressively poke various jokes whose major 'butt' is the dictator, Mubarak. The sacrosanct figure of the leader is intentionally and publicly degraded through jokes that address three major themes: the totalitarianism of his regime, his stupidity, and the corruption of his family. Laughter became a means of collectively moving beyond a category of the unspeakable that is politically-constructed and normalised through fear and intimidation. As Gilbert rightly argues 'one aspect of shared humour among marginalized groups is its tendency to unmask the unabashed hypocrisy of the dominant culture' $(2004,30)$. 
Collective humour becomes a means to publicly scrutinize the regime, expose its hypocrisy, and offend it. For instance, the people wave red cards to announce the exclusion of Mubarak from the political 'game'; they hold school-grade like panels in which Mubarak fails all the subjects including 'health services, education, industry, agriculture, commerce' (Prince 2014, 175); they satirically twist nationalist anthems and political poetry; and they draw grotesque political caricatures and graffiti. This myriad of comedic forms of dissent is what Miriam Cooke, in a different context, calls 'crafting insults' $(2017,42)$; it entails a collective construction of artistic, creative discourses of offending authority which signals 'the first step in the revolutions to come $[\ldots$ because] the politics of fear [i]s transformed into a politics of insult' (Cooke 2017, 39). Unlike Amiry's use of humour discussed in the previous section, which is more tactical and contingent upon existing incongruities in Palestinian life under occupation, revolutionary humour in Prince's is rather 'crafted'. The plots of jokes, chants, banners, and other comedic forms of dissidence are predominantly creative, imaginative, hypothetical, expandable, and generative. For instance, banners read:

Leave, My Arm is Aching

Leave, My Wife Wants to Give Birth

ctrl+alt+delete-Mubarak

[...]

Leave, I Want to Shower

$[\ldots]$

We also want to shave (Prince 2014, 143)

While collective dissident humour, as repeated and deployed by Prince, is generally directed against the figure of Mubarak, Prince's own targets of humour extend beyond the political. As we also see in Amiry, Prince deploys humour as a form of resistance to dominant patriarchal norms. The seemingly inclusive revolutionary moment appears to be hostile to social hierarchies, including gender barriers. Egyptian men and women conquered the streets calling for social and 
economic justice as the euphoria of freedom, a collective quest for democracy, a common enemy, and a shared- utopian- vision of a post-revolutionary nation bring them together. They became, as they chant, 'one hand' as gender roles were- superficially-blurred. Mixed-gender dancing, for instance, which would be in normal circumstances unconventional, was not only normalized during the revolution but also encouraged giving the impression of gender-equal atmosphere: '[women] joined the circle [of dancing], so the young men got more excited about dancing and so did we' (Prince 2014, 107). On the other hand, women were caught between being simultaneously accepted and denied in the square as a public sphere, and between the collective claims for national freedom and democracy and their womanly claims for gender equality, which arguably reflect their ambivalent status in revolutionary Egypt.

Prince uses humour as an attempt to dislocate and reverse gender roles as a way to shed light on gender issues as pivotal to the aspirations of the revolution. In one instance, Prince joins citizens' checkpoints at the entrance of Tahrir square to help check the demonstrators for security purposes. She then 'jokingly' grabs a young man while addressing him: 'finally, I get a chance to feel you up!'. While he becomes 'shocked and trie[s] to protect his body', Prince declares: 'it suddenly dawned on me that I finally had the chance to harass the men and to show them how it felt when they harassed us' $(2014,105)$. Prince seizes the carnivalesque circumstances of the uprising to reverse the 'male gaze', which is reminiscent of Amiry's comedic staring incident discussed earlier. Her humour, in this case, becomes both liberating and subversive. Throughout the narrative, Prince pokes fun at normative gender relations in Egypt not only as a way to stir conversations among the revolutionaries but also as a reminder that, as El Said et al. point out, "the forging of alternative gender norms is integral to resisting [political] authoritarianism' $(2015,9)$. 
In many occasions, Prince comedically- and flirtingly- harasses men and makes them uncomfortable: ‘may I make a pass at you? You're really cute!' $(2014,69)$, she tells an intimidated army man at Tahrir. While Amiry, as demonstrated earlier, uses self-deprecation in order to exploit and challenge gender norms by ostensibly subscribing to them, Prince reverses these norms as a way to shift the standpoints of gender-assault experiences whose victims are almost exclusively women. While Prince's attempts at gender-roles subversion are enacted humorously, they permit her to temporarily shift perspectives regarding the dominant patriarchal culture. Equally, this humorous attempt at role subversion aims, perhaps, at giving way to (re)new(ed) conceptions of gender paradigms and identities to emerge.

Prince's humorous problematization of existing gender-relations attempts to enact women's demands that are likely to be dismissed and deprioritized in favour of the national interests; it also exposes the ambivalent status of Egyptian women during the revolution. The superficial integration of women in the uprising scene was conditioned by predominantly nationalist agendas as their feminist demands were deprioritized in favour of the common, usually male dogmatic, interests. Women's growing presence in public spaces proved threatening to a patriarchal culture which is, as Mona Eltahawi describes it, embedded and exercised within a triangular paradigm: the state, the street, and the home $(2015,32)$. While the hegemony of the state was contested during the revolution, the other two patriarchal spheres continued to operate unchallengedly. Womanly presence in Tahrir square has been considered an act of spatialtransgression that needs to be contained. In revolutionary Egypt, sexual violence became 'a war tactic used by the counter-revolution to deny women their rightful access to public space by circumscribing their freedom of movement' and therefore 'their access to free expression' (Mehta 2014, 46). It is perhaps in response to these enduring realities that Prince appropriates the feminine 
Arabic term for revolution (thawra) and defiantly asserts 'Ismi thawra' ('Revolution is my Name') as a resistance act to these attempts to estrange women and distance them from public revolutionary spaces. Equally, she claims revolutionary Tahrir as a dwelling civic space of (her) womanly national engagement and visibility, and her (newfound) revolutionary identity: 'the midan was mine $[\ldots$ it] had become my home' $(2014,27,173)$.

\section{Conclusion:}

While, as the article demonstrates, the use of humour during politically-fraught contexts as a strategic, revolutionary means of dissidence can indeed disturb the power of the discourses it targets, it does not instantly resolve and practically change socio-political realities. Unlike Hélèn Cixous who symbolically equates the liberating aspects of women's writing with their laughter (1976) and claims that women's laughter in the face of power is able to practically alter genderbased injustices, Amiry and Prince's humour against the intersectional structure of power to which they are subjected proves limited in the short-term. Indeed, we laugh with Amiry at the Israelis' pride in their mud-like coffee, at their incongruous subjugating dynamics, at Ramallah's antianimal vet, and at the author's hallucinations. However, the consistent funniness of her text ends up on a sombre note which reflects the continuous 'tragicomedy' (Amiry 2006, 81) of the Palestinian predicament in which laughter becomes only possible 'through the fears/ tears' (Ilott 2015, 141, 152). Similarly, the hilarity of Prince's text is disrupted when the author is alienated from the 'real Egyptians' when she is sexually harassed by a fellow civilian; the sense of solidarity engendered by the 'laughing revolution' fractures within the narrative primarily due to genderbased violence.

Nevertheless, Amiry's and Prince's humour constitutes a part of a long-term dissident process. Being textually enacted and communicated, their comedic resilience problematizes norms 
in the long-term to potentially lead to a post-laughter sense of unsettlement and contemplation of possible norm revisions. As Barreca reasons, women's literary comedy 'can invert the world not only briefly but permanently' because it 'can strip away the dignity and complacency of powerful figures only to refuse to hand them back these attributes when the allotted time for "carnival" is finished' $(1994,33)$. Choosing to deal with and write revolutionary moments in a comedic manner, both authors rework the conventional forms of resistance (literature). By moving away from the lyrical frames of depicting national struggles, they highlight the strategic significance of humour in distorting stagnant hierarchical discourses as they reflect an awareness that 'once [a dominant power] has been degraded through laughter it somehow loses its semblance of power' (Ilott 2015, 137). Equally, their accounts maintain their comedic resilience by extending the duration of laughter to constitute a part of a textual archive of dissidence that acts as a reminder of the ludicrousness of power hierarchies and gender-based otherness which they ridicule. Thus, it becomes evident that, in Barreca's formulation, 'comedy permits, and prepares women for rebellion' $(1994,25)$ that ideally exceeds the revolutionary moment.

\section{Biographical note:}

Hiyem Cheurfa is a Ph.D. student and a Teaching Associate at the Department of English and Creative Writing at Lancaster University, UK.

\section{Acknowledgement:}

I am very thankful to Dr Lindsey Moore for her constructive feedback on an earlier draft of this article. 


\section{Notes:}

${ }^{\mathrm{i}}$ This is the view of Incongruity theory of humour, introduced by Thomas Hobbes (1991). See Carroll $(2014,16)$.

${ }^{\text {ii }}$ For Freud (1960), the release of aggression through laughter occurs through establishing a triangular relationship: a complicity between the teller of the joke and the audience, against the 'butt', or the object of ridicule.

iii One of the few contemporary, nuanced discussions on postcolonial/ feminist humour is the essay- collection Cheeky Fictions: Laughter and the Postcolonial (2005) in which the editors Susanne Reichl and Mark Stein highlight the modest engagement of postcolonial theory with humour studies. However, an emerging academic interest in postcolonial and feminist comedy can be observed in recent publications in the field, including the special issue of Comedy Studies (2018), edited by Helen Davies and Sarah Ilott which pays particular attention to issues of gender, sexuality and the body in postcolonial, feminist, and disability comedies. Equally, an edited collection within the same scope of interest by the aforementioned scholars, entitled Comedy and the Politics of Representation: Mocking the Weak, was published on 2018 by Palgrave Macmillan.

${ }^{\text {iv }}$ For more details on the history and etymology of humour in Arabic traditions, see Mubeen (2008).

" Sharon reoccupied Ramallah in 2002 and put it under curfew for around 42 days; a period which is central to Amiry's account.

${ }^{\text {vi }}$ Suzette A. Henke introduces the notion of 'scriptotherapy' to highlight the psychological significance of women's testimonial narratives, an act which she describes as: a way of 'writing out and writing through traumatic experience' (1998, xii),

vii See note iii

viii For further discussions on the chronotopes of Israeli occupation, see, for instance: Rashid Khalidi. 1997. Palestinian Identity: the Construction of Modern National Consciousness. New York: Columbia University Press); and Joseph Massad. 2000. 'The 'Post-Colonial' Colony: Time, Space, and Bodies in Palestine/ Israel.' In The Pre-Occupation of Postcolonial Studies, edited by Fawzia Afzal-Khan and Kalpana Seshadri-Crooks, 311-346. Durham, NC: Duke University Press.

ix In her Bodies that Matter (1993), Butler extends her discussion of the problematics of agency in relation to gender performativity initially reiterated in her Gender Trouble (1990) in which she controversially asserts that 'performativity contests the very notion of the subject' (33). In Bodies, Butler does not ultimately resolve this tension; she asserts that agency and subversion remain relative and conditioned by discourses, and gender performativity, mainly parody such as drag, does not necessarily destabilize normative gender/sex relationship.

${ }^{\mathrm{x}}$ For further discussions on feminism and the Palestinian national struggle see Anna Ball (2012).

${ }^{x i}$ Arabic for steadfastness. Used specifically, but not exclusively, to describe the Palestinian resistance (see, El-Said el al. 2015, 13). Sumud is a form of resilience which 'relies upon adaptation to difficulties of life under occupation, staying in the territories despite hardship, and asserting Palestinian culture and identity in response to Zionist claims' of legitimacy to the land (Ryan 2015, 299).

${ }^{x i i}$ Hajjeh is an Arabic term used to describe a Muslim woman who went to Mecca for pilgrimage. It is also often used to address elderly women.

xiii This is particularly reminiscent of the almost mythical images of two female figures of the Palestinian resistance: Leila Khaled (1944-) and Ahed Tamimi (2001-) whose activism has been publicly perceived as the epitome of Palestinian anti-colonial struggle. Similar to Khaled who has been caught between idealization and demonization for what has become known as the 1969 hijacking, 17 year-old Tamimi, who was detained by Israeli authorities from December 2017 until July 2018 for slapping an Israeli soldier, has gained unprecedented public attention for what is controversially considered as her bravery in the face of the oppressor.

xiv Arabic for resistance, mostly used in relation to the Palestinian case.

${ }^{\mathrm{xv}}$ Tahrir square in central Cairo.

${ }^{x v i}$ Standard Arabic and colloquial Egyptian, respectively.

xvii Mainly inspired by the infamous suicide of Tunisian street vendor Mohammed Bouazizi which triggered 'The Jasmine Revolution' in December 2010.

\section{References:}


Abaza, Mona and Samia Mehrez (eds). 2016. Arts and the Uprising in Egypt: The Making of a Culture of Dissent? The American University of Cairo Press.

Amiry, Suad. 2006. Sharon and my Mother-in-Law: Ramallah Diaries. London: Granta.

Awad, Sarah H. and Brady Wagoner (eds.). 2017. Street Art of Resistance. Palgrave Studies in Creativity and Culture.

Ball, Anna. 2012. Palestinian Literature and Film in Postcolonial Feminist Perspective. New York; London: Routledge.

Barreca, Regina (ed.). 1988. Last Laughs: Perspective on Women and Comedy. Amsterdam: Gordon and Breach Science Publishers, Inc.

Barreca, Regina. 1994. Untamed and Unabashed: Essays on Women and Humor in British Literature. Wayne State University Press.

Beattie, James. 1778. 'Essays on Laughter and Ludicrous Composition'. In Essays on Poetry and Music, James Beattie. Edinburgh.

Bergson, Henri. 2005. Laughter: An Essay on the Meaning of the Comic [Le Rire (1945)]. Trans, by Cloudesley Brereton and Fred Rothwell. Mineola, New York: Dover Publications, Inc.

Bernard, Anna. 2013. Rhetorics of Belonging: Nation, Narration, and Israel/Palestine. Liverpool: Liverpool University Press.

Bhabha, Homi. 2004. The Location of Culture. London, New York: Routledge.

Butler, Judith. 1990. Gender Trouble: Feminism and the Subversion of Identity. Routledge.

Butler, Judith. 1993. Bodies that Matter: on the Discursive Limits of "Sex". Routledge.

Butler, Judith. 2009. Frames of War: When is life Grievable?. London, New York: Verso

Carroll, Noël. 2014. Humour: A Very Short Introduction. UK, Oxford University Press.

Cixous, Hélèn. 1976. 'The Laugh of the Medusa'. Trans, by Keith Cohen and Paula Cohen, in Journal of Women in Culture and Society vol 1, n 4, 875-893.

Cooke, Miriam. 2017. Dancing in Damascus: Creativity, Resilience, and the Syrian Revolution. New York: Routledge.

El Said, Maha, Lena Meari, and Nicola Christine Pratt (eds). 2015. 'Introduction'. Rethinking Gender in Revolutions and Resistance: Lessons from the Arab World, edited by El Said et al. London: Zed Books.

Eltahawi, Mona. 2015. Headscarves and Hymens: Why the Middle East Need a Sexual Revolution. Great Britain: Weidenfeld \& Nicolson.

Freud, Sigmund. 1960. Jokes, and their Relation to the Unconscious. Trans, by James Strachey. Routledge \& K. Paul.

Frye, Northrop. 1965. Anatomy of Criticism: Four Essays, pp.43-48. New York: Atheneum.

Gilbert, Joanne R. 2004. Performing Marginality: Humour, Gender, and Cultural Critique. Detroit: Wayne State University Press.

Helmy, Mohamed M. and Sabine Frerichs. 2017. 'Sheherazade Says No: Artful Resistance in Contemporary Egyptian Political Cartoon'. Street Art of Resistance, edited by Sarah H. Awad and Brady Wagoner. Palgrave Studies in Creativity and Culture.

Henke, Suzette A. 1998. Shattered Subjects: Trauma and Testimony in Women's Life- Writing . UK: Macmillan.

Houlihan, Patrick F. 2001. Wit and Humour in Ancient Egypt. The Rubicon Press.

Hobbes, Thomas. 1991. Leviathan. Edited by Richard Tuck. Cambridge UP.

Hutcheson, Francis. 1750. Reflections upon Laughter and Remarks upon the Fable of the Bees. Glasgow: R. Urie for D. Baxter. 
Ilott, Sarah. 2015. New Postcolonial British Genres: Shifting the Boundaries. Palgrave Macmillan.

Kammoun, Raoudha. 2010. 'Humour and Arabs'. Dimensions of Humour: Explorations in Linguistics, Literature, Cultural Studies and Translation, edited by Carmen ValeroGarcés. Universitat De Valéncia.

Mehta, Brinda J. 2014. Dissident Writings of Arab Women: Voices against Violence. Abingdon: Routledge.

Moore-Gilbert, Bart. 2009. Postcolonial Life-Writing: Culture, Politics, and Self-Representation. Hoboken: Taylor and Francis.

Mubeen, Haris. 2008. 'Humour and Comedy in Arabic Literature (from the Birth of Islam to Ottoman Period). Al-Hikmat 28, pp. 13-30.

Prince, Mona. 2014. Revolution is my Name: An Egyptian Women's Diaries from Eighteen Days in Tahrir. Trans, by Samia Mehrez. Cairo; New York: The American University Press of Cairo.

Reichl, Susan and Mark Stein (eds). 2005.'Introduction'. Cheeky Fictions: Laughter and the Postcolonial, edited by Reichl and Stein. Amsterdam: Radopi.

Ryan, Caitlin. 2015. 'Everyday Resilience as Resistance: Palestinian Women Practicing Sumud'. International Political Sociology 9, 299-315.

Salem. Heba and Kantaro Taira. 2012. 'al-Thawra al-DaHika: The Challenges of Translating Revolutionary Humour'. Translating Egypt's Revolution: The Language of Tahrir, edited by Samia Mehrez. Cairo, New York: The American University in Cairo.

Zwagerman, Sean. 2010. Wit's End: Women's Humor as Rhetorical \& Performative Strategy. Pittsburgh, Pa.: U of Pittsburgh, Pittsburgh Ser. in Composition, Literacy, and Culture. 